\begin{tabular}{llllllllllllllllllllllllllll}
\hline A & C & T & A & A & R & C & H & A & E & O & L & O & G & I & C & A & C & A & R & P & A & T & H & I & C & A
\end{tabular}

\begin{tabular}{lr} 
VOL. LV (2020): 71-90 PL ISSN 0001-5229 \\
\hline
\end{tabular}

DOI 10.4467/00015229AAC.20.004.13509

\author{
EsZTER IsTVÁNOVITS, ${ }^{\oplus}$ VALÉRIA KuLCSÁR ${ }^{\circledR}$
}

\title{
A Roman Age Barbarian ELITE WARrior GraVe FROM CSENGERSIMA
}

\begin{abstract}
This is a preliminary publication of a warrior barrow grave with local cremation found in Csengersima (North-Eastern Hungary). From the point of view of the burial rite, it can be - in many regards - connected to certain barrow graves of the Przeworsk culture, and also to the barrow graves of the Early Roman Age found in the Upper Tisza Region (Slovakia and Transcarpathian area of Ukraine). Most of the objects find analogies in the Przeworsk culture. The unique find of the Csengersima grave is a combined chain-scale armour with scales leafed with gold.
\end{abstract}

Keywords: barbarian elite warriors, barrow graves, North-Eastern Hungary, Przeworsk culture

Csengersima is situated in the north-eastern corner of Hungary, in SzabolcsSzatmár-Bereg County, on the Szatmár Plain, left bank of the Szamos River. This is a border crossing point to Romania (Fig. 1).

The cemetery of the village lies in the centre of the settlement, on the bank of a former waterbed, on the NW corner of a nearly triangular hill (119 m above the sea level). In the summer of 1998, finds from the Period of Hungarian Conquest came to light here. ${ }^{1}$ Meanwhile, the northern part of the territory allotted for the cemetery was filled, so at this point, to occupy new pieces of land, they have started to demolish the 3.5-4 m high cemetery hill situated in the middle and having been unused for the last 100 years (Fig. 2: 1). That is why the excavation has begun and that is how the Roman Age burial represented here was found. ${ }^{2}$

After clearing the wall of the section, it became obvious that the cemetery hill was "erected" on a relatively small barrow (height: $120 \mathrm{~cm}$, diameter: 10-15 m) in the $18^{\text {th }}-19^{\text {th }}$ century. Modern Age burials dug into the cemetery hill haven't disturbed the Roman Age burial. Our test section covered somewhat more than

${ }^{1}$ Jósa András Museum, Archaeological Archive 2001.122.

${ }^{2}$ The excavation was led by Attila Jakab. 


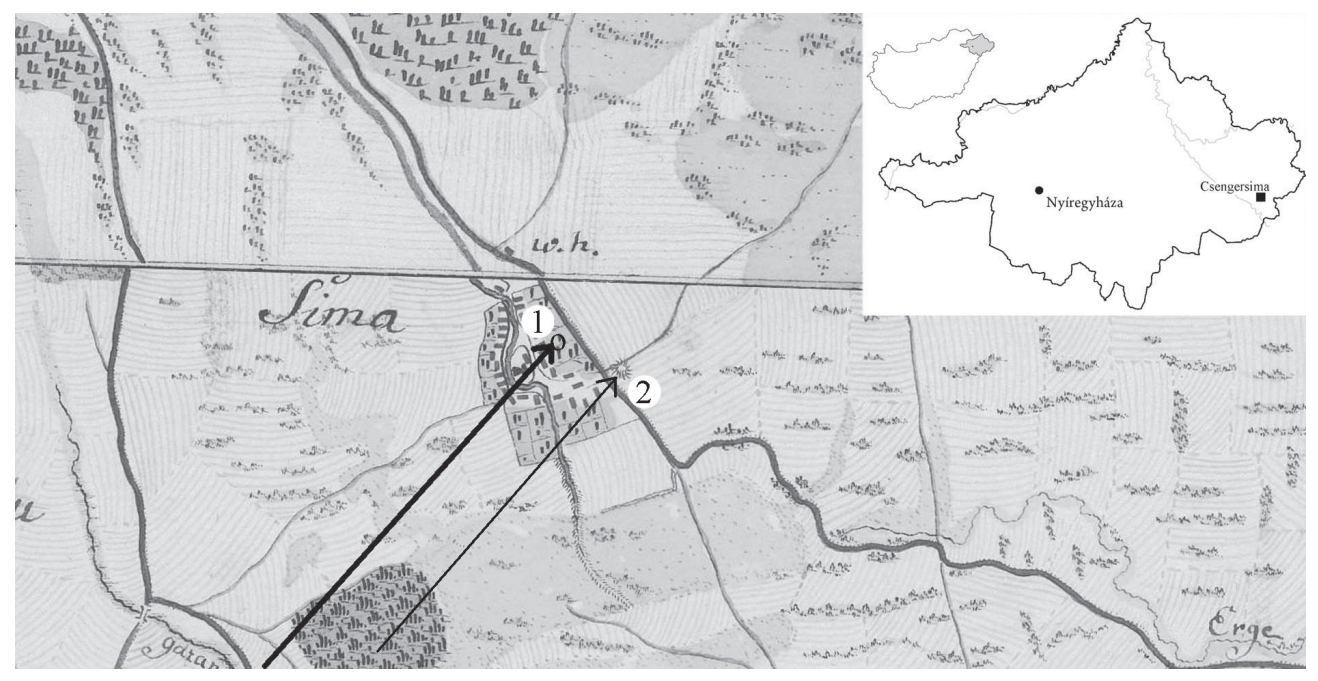

Fig. 1. The site and its vicinity in Csengersima on the First Military Survey map made between 1780-84, 1: site; 2 : barrow nearby

a quarter of the Roman Age barrow (Fig. 2: 2). ${ }^{3}$ Under the barrow, we excavated traces of a single(?) cremation burial. Ashes ${ }^{4}$ came to light partly scattered on the original daily surface, partly in two pits. The same can be said about the relatively large number of objects. Original daily surface burned red (Fig. 3: 3) and was covered by charcoal on different scale. Burning is more significant towards the centre of the barrow; the pyre must have been there. Around the middle of the excavated area, under the burned layer, we found a small rectangular pit with rounded corners. It contained a lot of finds (Fig. 3: 1). Close to it, there was another pit of similar size and fill, however, a later pit almost completely destroyed it. Only $15 \mathrm{~cm}$ of its bottom survived. It had no finds (Fig. 3: 2). Fill of these features was burned, with a lot of charcoal. The remained pit's ground space was $100 \times 69$ $75 \mathrm{~cm}$, it was $42-46 \mathrm{~cm}$ deep, oriented N-S 5-185', its walls were vertical and on the eastern side slightly arched inside. Its bottom was slightly elevating towards $\mathrm{S}$, while around the NW corner, a relatively small, 3-5 cm deep concavity of $27 \times 17$ $\mathrm{cm}$ diameter could be observed where finds concentrated more intensively. Finds: fragments of a terra sigillata (Fig. 4), handmade pottery (Fig. 5), bronze and iron objects, cremated bones.

${ }^{3}$ Demolition of the cemetery hill was stopped because of the archaeological site, so further parts of the Roman barrow could not be investigated.

4 Traces refer to a high temperature burning. From the other hand, the flood soil did not preserve the bones, so we were able to collect only few of them. 

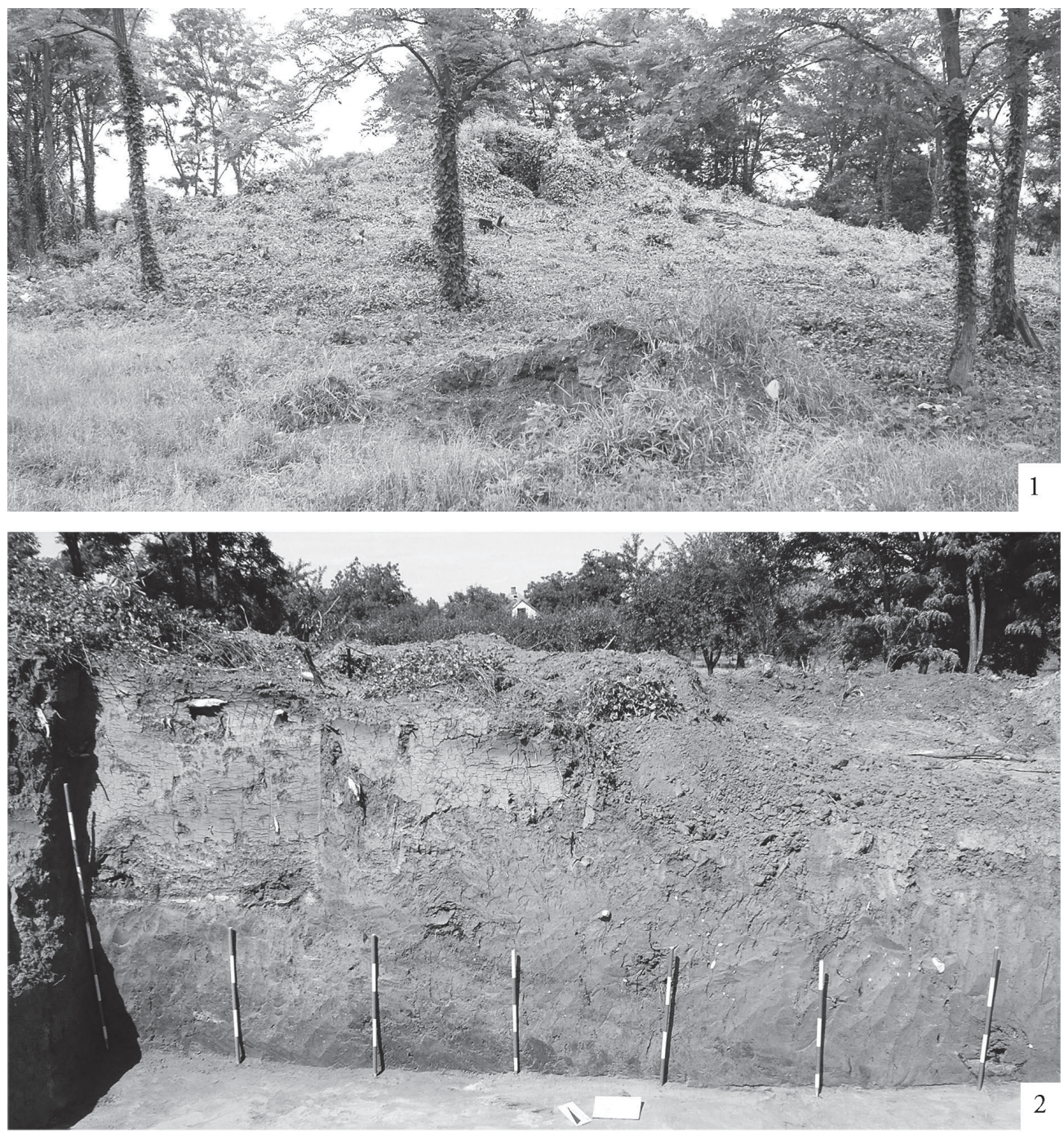

Fig. 2. 1: Csengersima, the 3.5-4 m high cemetery hill; 2: the Roman Age barrow on the northern wall of the section 


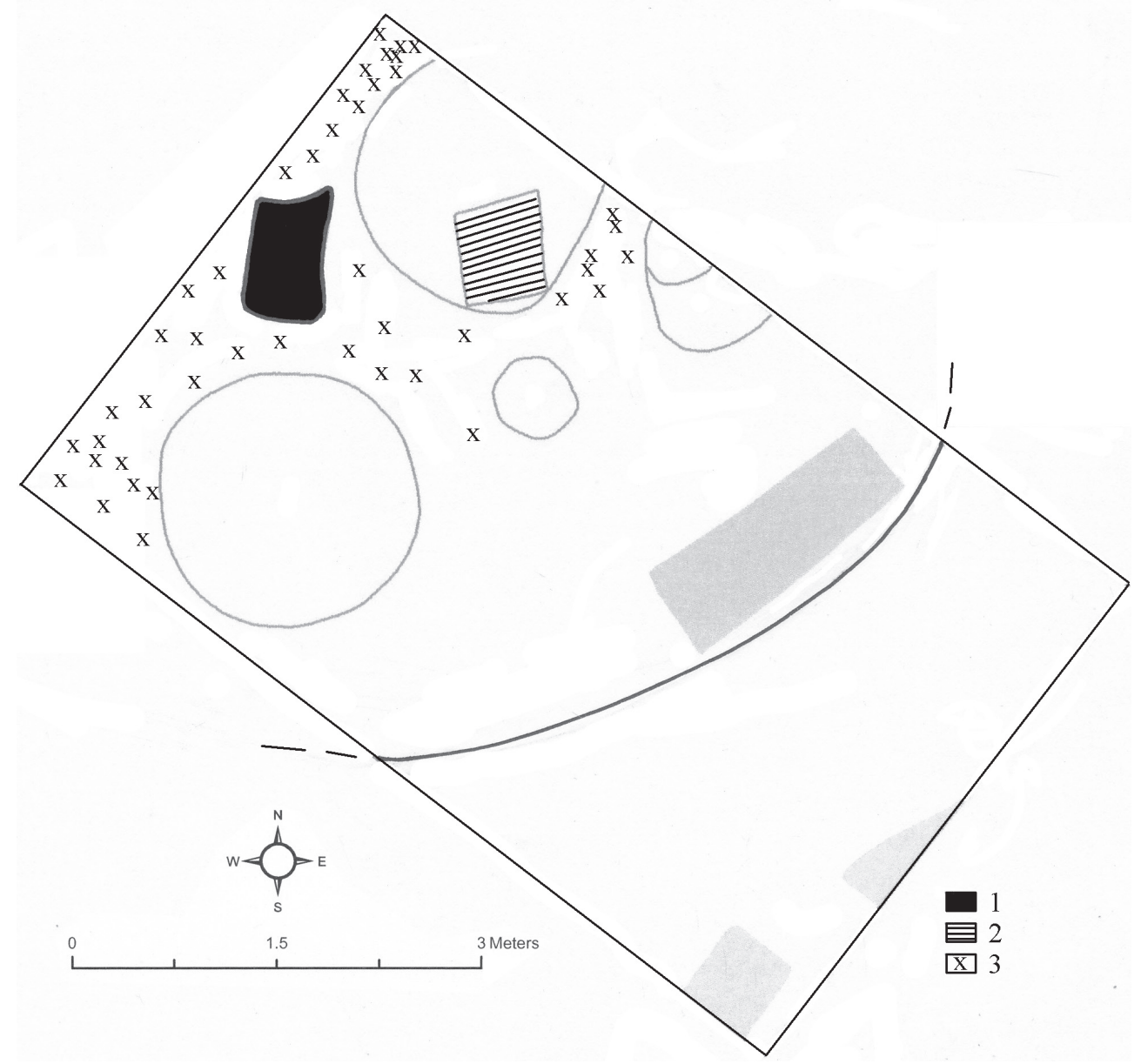

Fig. 3. Csengersima, original daily surface, 1: pit grave; 2: probably Roman Age feature;

3: a part burned red

The burial is dated by a Drag. 37 type terra sigillata with Cinnamus master mark to $140-180 \mathrm{AD}$ post quem (Fig 4$).^{5}$

All the objects were burned, fragmentary and scattered. Beside the relatively large number of pottery, more than $600 \mathrm{~g}$ of iron remains and more than $1 \mathrm{~kg}$ of bronze/silver ${ }^{6}$ remains got to the museum. There are ten vessels of more or less clear profile and further fragments of at least ten more vessels in the find material.

${ }^{5}$ We thank Dénes Gabler for determining the piece.

${ }^{6}$ This is the weight before cleaning. 


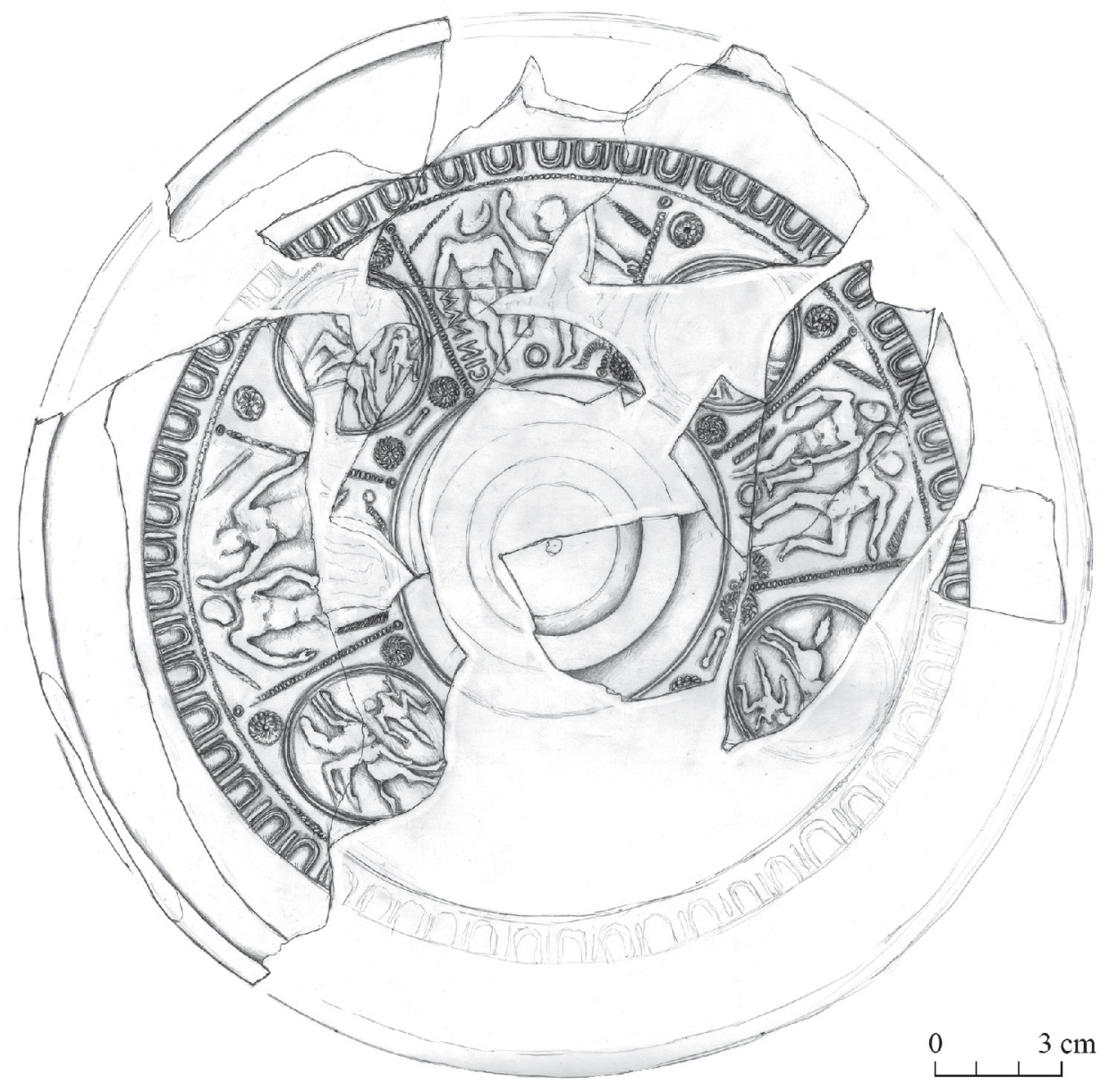

Fig. 4. Fragments of a terra sigillata from Csengersima

Judging from the observations described above, the richly equipped dead could have been burned locally on a rather large pyre together with his objects. After that, remains were pulled into one, perhaps two(?) pits (hardly any of the second pit survived and no finds came to light from here) without special care.

It is a question, whether we speak about a single grave. We have $19^{\text {th }}$ century data according to which there may have been another mound in the vicinity (Jakab, Istvánovits 2011, 29). This is supported by the First Military Survey map made between 1780-84, where $200 \mathrm{~m}$ ESE of our site a mound was depicted (Fig. 1: 2). These mounds are low, hardly elevating above the surface, so it is possible that we found one of the burials of a barrow cemetery. 


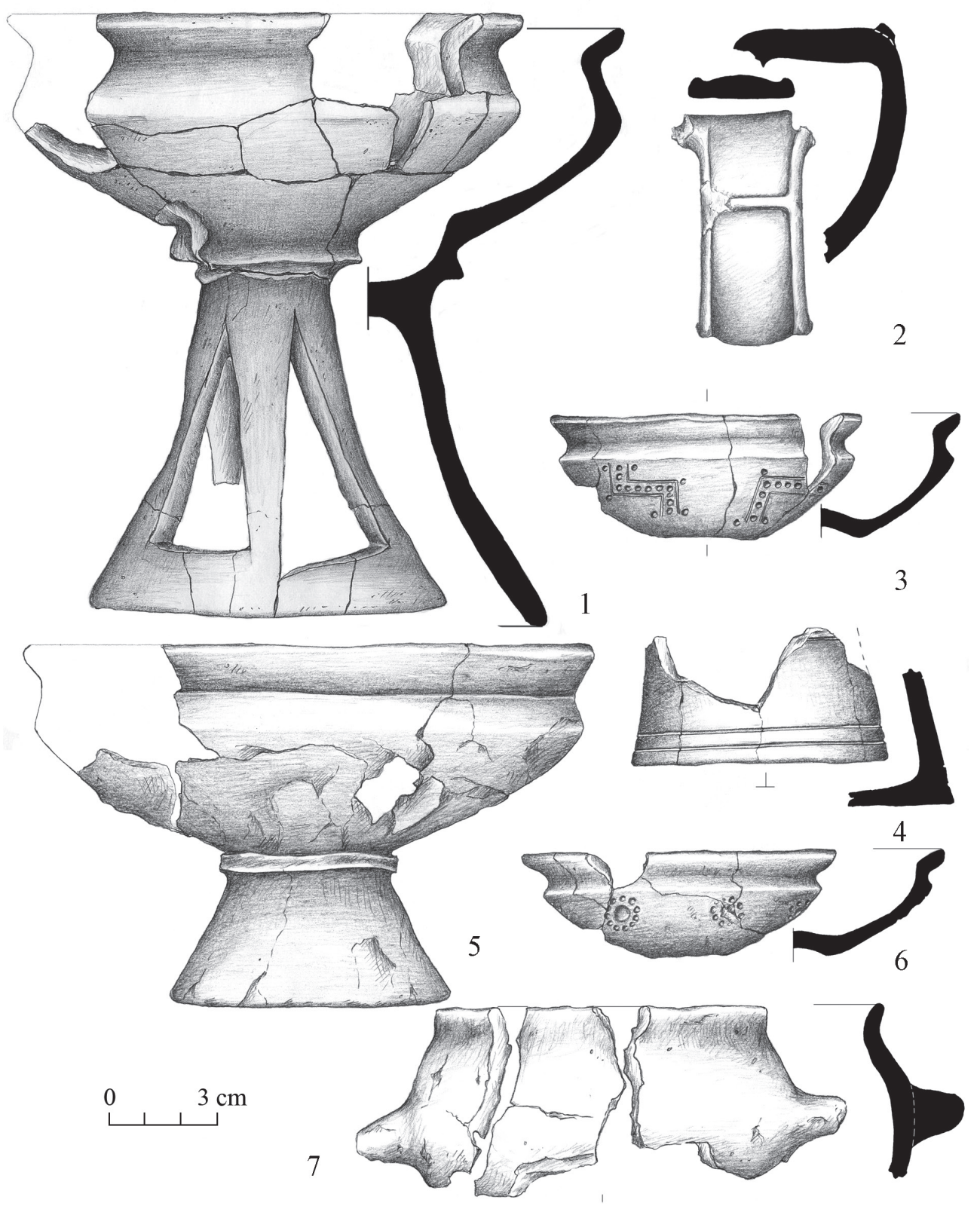

Fig. 5. Selection from the ceramic material of Csengersima 
We know several traces of Roman Age settlements in the vicinity (Jakab, Istvánovits 2011, 41). Among them, a large scale (7.8 hectares) excavation was conducted at the border checkpoint situated 3.3-3.5 km from the site in question (Gindele, Istvánovits 2009, 2011). Its material has been evaluated, so it is clear that at the moment of the burial, the settlement was alive: its lower chronological border can be put to the turn of the $1^{\text {st }} / 2^{\text {nd }}$ century AD. Despite of it, interestingly enough, pottery from the burial and from the settlement is different.

\section{BURIAL RITE}

The main features of the rite in the burial of Csengersima are the following: 1 . Barrow grave. The mound is low and not big in diameter. 2. Local cremation: together with the dead, his objects were burned on pyre (or burned after the mourning feast?). 3. Objects burned together with the dead were pulled into one (or two) grave pits. 4. Among the finds, objects characterising the Przeworsk culture dominate. 5. Mostly heavily burned shards were found scattered under the mound.

As to the burials, we can assume that number of graves found in the Upper Tisza Region and dated to the late $2^{\text {nd }}-3^{\text {rd }}$ century $\mathrm{AD}$ - apart from Sarmatian territory - is rather low, it hardly reaches $50 .{ }^{7}$ Most of them are cremations, ${ }^{8}$ with the exception of the characteristic graves of the Leuna-Haßleben-Zakrzów type Germanic elite in Eastern Slovakia: Céke/Cejkov and Osztrópataka/Ostrovany (Beninger 1931; Prohászka 2006). Apart from the finds, we do not have information on most of the further sites or have only rough data. Presently, it seems to us, that there are two kinds of burial rites we can count with: most of them are urned or unurned graves in simple pits and there are only some barrow ones. We can also assume that the find material - apart from some exceptions ${ }^{9}$ - can be attributed to the Przeworsk culture, with data referring to the domination of warrior burials. ${ }^{10}$

From the point of view of Csengersima, we have to examine the group of barrow graves/cemeteries:

${ }^{7}$ Presently, we know 53 cemeteries or sites referring to burials (Kotigoroshko 1988; Kobály 1998; Gindele 2010/11, 229, map 2; Olędzki 2014 - all with further references).

${ }^{8}$ Among 23 sites in NW Romania, ten are inhumation cemeteries situated in the valley of Ier (Gindele 2010/11, 229, map 2). Judging from their rite and finds, with great probability, they can be associated with Sarmatians: in the valley of Ier, Sarmatians expanded up to the line of the Ecsedi marsh and occupied this territory (Istvánovits, Kulcsár 2017, 323, Fig. 268).

${ }^{9}$ One of the exceptions is Medieşu Aurit - according to our present knowledge - unique in all aspects. Mostly it is considered the legacy of a mixed Dacian-Przeworsk population (Matei, Stanciu 2000, Nr. 162, 66; cf. Olędzki 2014, 318 - with further references).

${ }^{10}$ Prevailance of warrior graves - at least partly - can be obviously explained by the fact that among stray finds, weapons represent the characteristic and relatively big objects that were typically donated to collections by the finders. 


\section{Bratovo-Halottdomb}

In 1976, V.G. Kotigoroshko excavated the largest (42x34 m, height 100-120 cm) member of a barrow group consisting of four mounds on the bank of river Botar. The one in question stayed separately, some $400 \mathrm{~m}$ from the rest. Under the centre of the barrow, there was a rectangular, $15 \times 9.2 \mathrm{~m}$ large pyre oriented $\mathrm{E}-\mathrm{W}$. Thickness of charcoal sometimes reached $10-13 \mathrm{~cm}$. There were scattered pottery and bronze fragments (among them burned secondarily) and a few calcinated bones in the fill. At the eastern edge of the barrow, four burials were found in a rectangular, $8.8 \times 4.8 \mathrm{~m}$ large, $30 \mathrm{~cm}$ deep pit: two urned burials (in one of them female bones, in another one bones of a dog sized animal) and two cremated burials: that of a man and a woman. Under the pyre, $180 \mathrm{~cm}$ from the large pit, a fifth burial was found: a female cremation grave. Beside the two urns, there were shards (among them partly burned fragments of a Drag. 37 type terra sigillata), knives, iron ring, spurs, spears, umbos, shield handles, iron rod, scissors, key, fibulas, bronze object, iron nail, and beads (Kotigoroshko 1988; Szathmáry 1988).

Iza

This cemetery situated in the narrow valley of the Carpathian foothills, consisting of several groups of barrows first was excavated in 1939 by P.P. Sava. In 1941, E. Zatlukál investigated 15 barrows founding in 13 of them handmade urn and remains of pyre in the fill. From 1948, excavation was continued by M.Yu. Smishko, he worked in the same group of barrows as Zatlukál revealing further 11 mounds. This grave group got into the scholarship under the name of Iza I. The site of Iza II is situated $2 \mathrm{~km}$ from the latter. It was also Smishko who started its research excavating three barrows. Kotigoroshko continued work in 1975, revealing further four barrows. It was also him, who in the next year investigated remaining 12 barrows of Iza I. Originally, these two sites probably made one cemetery consisting of around 80 barrows that were situated in four groups. The 4-5 km long site was oriented NE-SW, it could be used in the $1^{\text {st }} 4^{\text {th }}$ century AD. Diameter of the barrows is $8-10 \mathrm{~m}$, height: $25-50 \mathrm{~cm}$. In most of them, remains of pyre were found under the mound, ${ }^{11}$ that is to say, these were the cases of local cremation. Under the pyre or close to it, there were one or two pits with mostly urned (in many cases only the bottom of the urn remained), more rarely with unurned burials. Usually, there were 2-4 urns. Anthropological examination revealed that part of the barrows served for collective burials, but there were also individual ones. Most of the urns were handmade, sometimes they were covered.

${ }^{11}$ When no red burned spot referring to pyre could be observed, it could be explained by the poor state of the barrows, in the case of which ploughing reached the ancient surface. 
In some cases, remains of the pyre were pulled into a special pit. Dispersing of shards of the ritually broken vessels on the surface under the barrow, in the grave pit itself, in the earth of the mound is especially characteristic. Shards are frequently burned, sometimes slagged. Most of the objects - shards, beads, bucket pendant, spindle whorls, fibulas, spear, buckles, knives - were burned. (Kotigoroshko 1977; 1980; Smishko 1952; 1960, 77-80, 115-116).

\section{Lazuri-Lubi-tag}

There are two barrows oriented NE-SW, $30 \mathrm{~m}$ from each other. In 1995, one of them was excavated by a joined Romanian-Ukrainian team. Its original diameter was $32 \mathrm{~m}$, height $90 \mathrm{~cm}$. The surface under the barrow was encircled by a ditch, inside it smaller and bigger pits (depth: 10-20 and 40-70 cm), burned surface, fills containing charcoal and ashes were recorded. Part of the features in the middle of the surface was surrounded by 11 postholes arranged rectangularly. A total of 40 pits came to light (including the postholes). Two larger pits were recorded: inside and outside the circular ditch. Beside calcinated bones and charcoal, there were fragments of burned glass, bronze, gray wheelmade pottery (fragments of bowl and storage vessel) and handmade (pots') fragments, pieces of burned plaster, bronze bell, small fragments of ring mail shirt from two features. According to V.G. Kotigoroshko, pottery was made locally in the Late Roman Age pottery kilns found in the site Béla-rét. On the basis of the pottery, he dated the barrow to the $3^{\text {rd }}-4^{\text {th }}$ century $\mathrm{AD}$ and emphasised its similarity with Carpathian Barrows culture not trying, however, to make ethnical determination (Kotigoroshko 1998).

\section{Zemplín-Szélmalom-domb}

A total of 177 burials were excavated here, between 1958 and 1963 by K. Andel and mainly by V. Budinský-Krička, then between 1970 and 1974 by M. LamiováSchmiedlová. Burial rite was extremely heterogeneous, the only common feature was that all them were cremation graves. A total of 15 barrows was recorded. Under a barrow 1-26 burials were found. Further graves were situated between the barrows. Mounds were not unified: in two of them (barrow 1 and 8) there was local cremation. At the former, a stone ring encircled the pyre, and under the latter barrow large stones were also observed. An emphasised difference from the rite of the three other sites is that here in both barrows with local cremation, ashes and finds were recorded on the original surface, there was no grave pit. The cemetery of Zemplín was used in the last years of the $1^{\text {st }}$ century BC - first years of the $1^{\text {st }}$ century AD. There were different cultural and chronological horizons observed, among them Late La Tène, Dacian and Przeworsk ones, the latter dating from $\mathrm{C} 1 \mathrm{a}$ judging from shield bosses and grips. Four Przeworsk graves 
were earlier, dated to B1c-2c. (Budinský-Krička, Lamiová-Schmiedlová 1990, 245-344, pls. I-XXII; Olędzki 1999, 105-108).

Beside the sites mentioned above, V.G. Kotigoroshko listed the following ones: Liskovje, Kalnik, Kljucharki, Lipcha and Ruske Pole (Kotigoroshko 1991, 154). However, these sites cannot be definitely dated to the Roman Age. In case of Liskovje we know only that charcoal and coarse shards were found in the area of the barrows and "in this region" - according to T. Lehoczky, a Maximinus coin with loop dated to 238 was found (Lehoczky 1892, 76). In Kalnik, in one of the several barrows, the local Greek Catholic priest digging a barrow in 1879, found a Constantinus gold mint from 337-340. Also here, shards and ashes came to light. However, these data are very uncertain (cf. Lehoczky 1892, 82). About Kljucharki we only know that there were barrows, and in 1881, the forester found a silver coin in his land. But nothing is said about its finding in any of the barrows (Lehoczky 1892, 91). Actually, we have no information about Lipcha. Here Kotigoroshko refers to his own study (Kotigoroshko 1980), in which, however, no substantive data were published. Finally, barrows of Ruske Pole were described by J. Mihalik. He excavated one of them (Mihalik 1892), but the dating of this cremated burial under barrow would be possible only on the basis of the urn found here, however, unpublished. So, the age of the site is questionable.

Based on the above, if we want to evaluate barrow graves, in the Upper Tisza Region, we should take into consideration only the above mentioned four sites and Csengersima.

Their common feature is the presence of burials cremated locally. Among them the first known and biggest one is the cemetery of Iza. In connection with this site it was suggested that it shows close similarity with the Carpathian Barrows culture spread east of the Carpathians and dated to the Roman Age. The idea was that people of the Iza cemetery belonged to the same population as the culture that existed east of the Carpathians. Further scholarship - on the first place, V.G. Kotigoroshko - related Iza with all barrow graves found later. At the same time, L.V. Vakulenko, an outstanding specialist of the Carpathian Barrows, drew attention to the fact that from the very beginning, barrow graves on the two sides of the Carpathians were "conflated" by the scholarship. It is characteristic, for example, that I.P. Rusanova in her summarising work on the culture in the series "Arkheologia SSSR", published drawings of the Iza finds (Rusanova 1993). After comparing cremation graves in barrows of the regions Transcarpathia and Ciscarpathia - Vakulenko came to the opinion that in this regard we find more differences than similarities (Vakulenko 2004). The final conclusion was that in the Late Roman Age these two regions were absolutely different from ethno-cultural point of view (Vakulenko 2004, 98).

Presently, it seems to us that local cremation in barrows - though it is much rarer here - appears in Transcarpathia earlier than east of the Carpathians. 
The find material of the Csengersima barrow - and at least partly of the barrows from the Transcarpathian Region - can be clearly associated with the Przeworsk culture, so we cannot neglect the question whether the rite itself may be connected with the culture. Custom of erecting barrows did not spread widely in the territory of the Przeworsk culture but appeared in several places. For example, in Siedlemin and its vicinity - Kapalica, Roszkowo (central Poland, Jarocin district), and in Parzęczewo (Grodzisk Wielkopolski district) - several barrows of Roman Age were found. Their special feature is that the dead were cremated locally so that the surface chosen for cremation was levelled and covered with clay, forming circular or rectangular surfaces. After that remains of the pyre (including the grave-goods) were placed scattered on several dozens of square meters, erecting the barrow above them. These burials were dated to period B2-C1 (Kostrzewski 1917, 115-116, 192; Żychliński 2013, 114). Barrow graves of the Przeworsk culture were collected between the two world wars by A. Karpińska (Karpińska 1926) and relatively recently, correcting the previous research, by H. Janaczek, who recorded a total of 30 sites with certainly Przeworsk barrow graves (Janaczek 1990) and separated basically three types of barrows. Most of all, Csengersima can be related to the Siedlemin type dated to C1 (Janaczek 1990, 123-126), differing only because of the lack of stone constructions. The main common feature is the local cremation, traces of which were found under the barrows.

A good summary of the cremation burials with barrows of the age was published by V. Budinský-Krička and M. Lamiová-Schmiedlová (BudinskýKrička, Lamiová-Schmiedlová 1990, 303-306). They drew the attention of the researchers to the fact that this custom - erecting barrow above local cremation - can be found already in Early Roman Age Transylvanian Dacian(?) milieu (Macrea 1957, 150).

If we accept L.V. Vakulenko's opinion based on systematic research, according to which sites of the Upper Tisza Region are independent from the Carpathian Barrows, and if we take into consideration the chronological situation - they are earlier than the Ciscarpathian ones - then we should seek for the origin of the population with Przeworsk find material, appearing in the NE corner of the Carpathian Basin in another place. From one hand, we can consider connections with Siedlemin or, perhaps, Dacian origin, from the other hand, the local earlier population. In the first two cases it is the long distance which is problematic, in the latter case it is the chronological hiatus. Taking into consideration the earlier inhabitants of the region, we should go back to the Kushtanovica/ Kustánfalva culture, where similarities are shown up in the burial rite. It was V.G. Kotigoroshko who first suggested it, and, concluding from this, associated the population of the Carpathian Barrows with Thracians (Kotigoroshko 1980, 239). 
At the moment, we are unable to bridge the space and time span, so we shall leave unanswered the question of formation of Transcarpathian burials with local cremation. The find material itself can be undoubtedly associated with the Przeworsk culture, while the find material of contemporary settlements is obviously heterogenous, so the dead buried in Csengersima and similar sites should be connected with a Vandal/Victoval population. It is a question which mountain pass should be taken into consideration in case of their immigration: Dukla, Uzsok or Verecke; or should we suggest the acculturation of some groups of local inhabitants?

\section{POTTERY}

A good analogy of the open-work pedestaled bowl (Fig. 5: 1) can be cited from grave 32 of Chmielów Piaskowy dated to period C1a. This type spread in the southern and south-eastern regions of the Przeworsk culture. Open-work pedestals came to light in largest number in the cemetery of Gościeradów (Kraśnik district) dated to period B1/B2-C2 (Godłowski, Wichman 1998, 32, 71, Taf. XLVIII: 2). A fragment of a similar bowl was found in the Upper Tisza Region in one of the graves of Badon-"Doaşte" (Stanciu, Matei 2006, Pl. II: 6). Another vessel of the same cemetery - kind of a situla? - can be cited as a more remote analogy to the Csengersima finds (Stanciu, Matei 2006, Pl. I: 3).

Analogies of the not open-work pedestaled bowl (Fig. 5: 5) can be cited also from the cemetery of Chmielów Piaskowy, from graves 30NE and 43 dated to phase B2. Type II/3 by T. Liana (Liana 1970, 439) was found in this cemetery in graves dated to phase B2; the only exception is a burial dated to B2/C1. This is in accordance with the dating of vessels found in other Przeworsk cemeteries (Godłowski, Wichman 1998, 30-31, 38, 71, Taf. XLIV: 2, LXIX: 2).

Two small, decorated bowls belong to a characteristic Przeworsk type (Fig. 5: $3,6)$. Close analogy can be cited from Pakoszówka (Madyda-Legutko, PohorskaKleja, Rodzińska-Nowak 2006, 79, Fig. 10:1; Madyda-Legutko, RodzińskaNowak, Zagórska-Telega 2013, 410, Fig. 2: 1). At the same site, a polished, high, rectangular pedestal was found similar to the one from Csengersima (Fig. 5: 4) (Madyda-Legutko, Pohorska-Kleja, Rodzińska-Nowak 2006, 79, Ryc. 9: 2, Ryc. 10: 8, Madyda-Legutko, Rodzińska-Nowak, Zagórska-Telega 2013, 410, Fig. 2: 8).

Analogy of the vessel with coarser surface and plain knob-handle (Fig. 5: 7) comes e.g. from feature 70 of Pakoszówka 70. According to the publishers, this type of pottery characterises the Early Roman Age Dacian cultural community (Madyda-Legutko, Pohorska-Kleja, Rodzińska-Nowak 2006, 79, Ryc. 6: 6, Ryc. 8: 2; Madyda-Legutko, Rodzińska-Nowak, Zagórska-Telega 2013, 410411, Fig. 2: 9). 


\section{CHAIN MAIL SHIRT AND PIECES OF SCALE ARMOUR}

The unique object of the Csengersima find is a composite armour consisting of chain mail and scale armour (Fig. 6). The links of the chain are not exactly similar, their diameter varies between 0.6 and $0.7 \mathrm{~cm}$, their thickness is mostly $0.1 \mathrm{~cm}$. Each ring is connected with four others. Before cleaning, their common weight was $241.6 \mathrm{~g}$. Beside pieces of chain, we were able identify more than 50 scales, their width varying between 2 and $2.1 \mathrm{~cm}$, and length between 2.7 and $3.1 \mathrm{~cm}$. The weight of the most complete piece after cleaning is $2.73 \mathrm{~g}$. The iron scales have characteristic and unique roughed surface covering most part of the facial side, on several pieces we could observe that originally, they were covered by golden plates, so the rough surface, perhaps, served good adherence. There are holes on the upper edge of the scales, but no rivets were observed on any of them. Their common weigh exceeded $270 \mathrm{~g}$ before cleaning. ${ }^{12}$

Pieces of chain are relatively regularly met in Przeworsk burials, e.g. in grave 208 of Krupice dated to period B2/C1. It consists of 200 (mainly iron and some bronze) rings. This is the third such find in Podlasie. Such fragments are found as Roman import mainly in Lesser Poland and Silesia. The other main territory of spread is the Elba Region. In the Krupice grave a young woman was buried (Jaskanis 2005, 53-54, 100, Taf. LX: 4). This is not unusual: fragments of chain mail frequently come to light from female and child graves of the Przeworsk culture, obviously placed as amulets (Czarnecka 2013, 168-169). However, it must
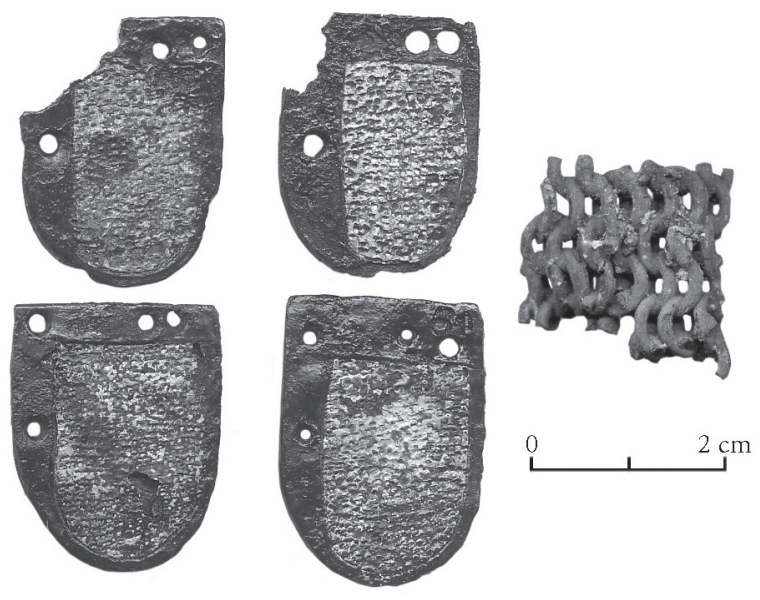

Fig. 6. Parts of the composite armour consisting of chain mail and scale armour from Csengersima

${ }^{12}$ We should also mention bronze (1084.02 g) and iron (119.53 g) lumps that in their present state cannot be associated with any of the recognisable objects. 
not be the case in the Csengersima assemblage. Pieces of chain mail weighing almost quarter of a kilogram before cleaning could not be amulets. In addition, we should emphasise that these fragments, in all probability, stand together with the pieces of scale armour. ${ }^{13}$

From the Upper Tisza Region we know chain mail shirts from grave 78 of Zemplín and from Malaya Kopanya. Judging from a spearhead, the latter can be dated to period B1. Here, remains weighing $4 \mathrm{~kg}$ were collected. The diameter of the rings is $8 \mathrm{~mm}$, they are $1 \mathrm{~mm}$ thick. Pieces from Csengersima are much more delicate: the average diameter of the chains is only 6-7 mm, thickness: $1 \mathrm{~mm}$. According to I. Kobal' "The cultural attribution of the find is highly disputable. One of the spearheads is a typical Przeworsk form being one of the evidences for the earliest contacts between the local (Dacian) population and that of the Przeworsk culture from the arch of the Northern Carpathians. At the same time, the chain mail is more probably Dacian which can be suggested on the basis of the examination of the Zemplín chain mail from one hand, and by the Dacian hillfort situated some hundred meters from the site of the chain mail" (Kobály 1998, 120). He interpreted the find as of a high rank leader similarly to the dead with chain mail from Zemplín.

Publishers of the Zemplín find also consider the chain mail's owner high ranking Dacian leader. In this case the rings are again larger than the ones from Csengersima: their diameter is $8-9 \mathrm{~mm}$. This is one of the heaviest mails among the Roman Age pieces: around $9.5 \mathrm{~kg}$. A characteristic feature of the burial similarly to Csengersima ${ }^{14}$ - is that further weapons are missing from the grave (Budinský-Krička, Lamiová-Schmiedlová 1990, 283-286). Similar phenomenon was earlier observed by G. Waurick, who in his seminal article overviewing the Roman Age mail armour both from the Empire and Germania Libera, pointed out the lack of weapons in several Germanic warrior graves, emphasising among them the case of the Kemnitz armour. In his opinion, the latter was buried not as piece of defensive armour but as an expensive (valuable) object similarly to other Roman imported goods (Waurick 1982, 114).

In the Upper Tisza Region, a fragment of a mail shirt was found also in the Przeworsk grave dug into a Copper Age barrow in Lesne (here, the rings were 1-1.1 cm large, that is to say, even rougher than the ones from Zemplín), and we also have uncertain data from Mukachevo (Budinský-Krička, LamiováSchmiedlová 1990. 283-284).

Roman infantry chain shirts usually consisted of rings that were $7 \mathrm{~mm}$ in external diameter and $1 \mathrm{~mm}$ thick. Rows of chains were alternate, consisting of

\footnotetext{
${ }^{13}$ Of course, there is a possibility that one of the armour types belonged to helmet, and only the other one belonged to body armour.

${ }^{14}$ However, here we have to underline that in Csengersima - lacking the complete excavation of the barrow - we cannot be sure that there were no further weapons in the grave.
} 
stamped and welded rings and riveted rings. E.g. a fragment of a mail found in Iža and dated to the period of the Marcomannic Wars, contained of 6-7 mm large links (Rajtár 1996, 93, Abb. 7: 13). This is not the case in Csengersima: all the rings are welded (there is a thickening part on each of them, probably, showing the trace of welding) and the rows are identical (Fig. 7). Sometimes pieces of Roman scale armour were tinned in an alternate way, so as to show a gold and silver pattern (Stephenson 2001, 34-35).

In the Roman world, the combination of mail and scales is known - however, rarely - in the case of the so-called lorica plumata. This type of armour was made, as usually, from alternating rows of riveted and solid rings, using the riveted ones for threading the scales. The latter were ribbed, all together giving the impression of feathers (Wijnhoven 2009, 3). This is not the case in Csengersima, where, as we have mentioned above, all the rings are solid, and the scales have no ribs, but very special golden decoration (Fig. 6). Anyway, at least the idea of combining rings and scales is close to our armour. Lorica plumata, or - as M. Wijnhoven suggests calling it - lorica hamata sqamataque was used from the middle of the $1^{\text {st }}$ - end of the $2^{\text {nd }}$ century $\mathrm{AD}$, which, more or less, fits into the dating of our assemblage.

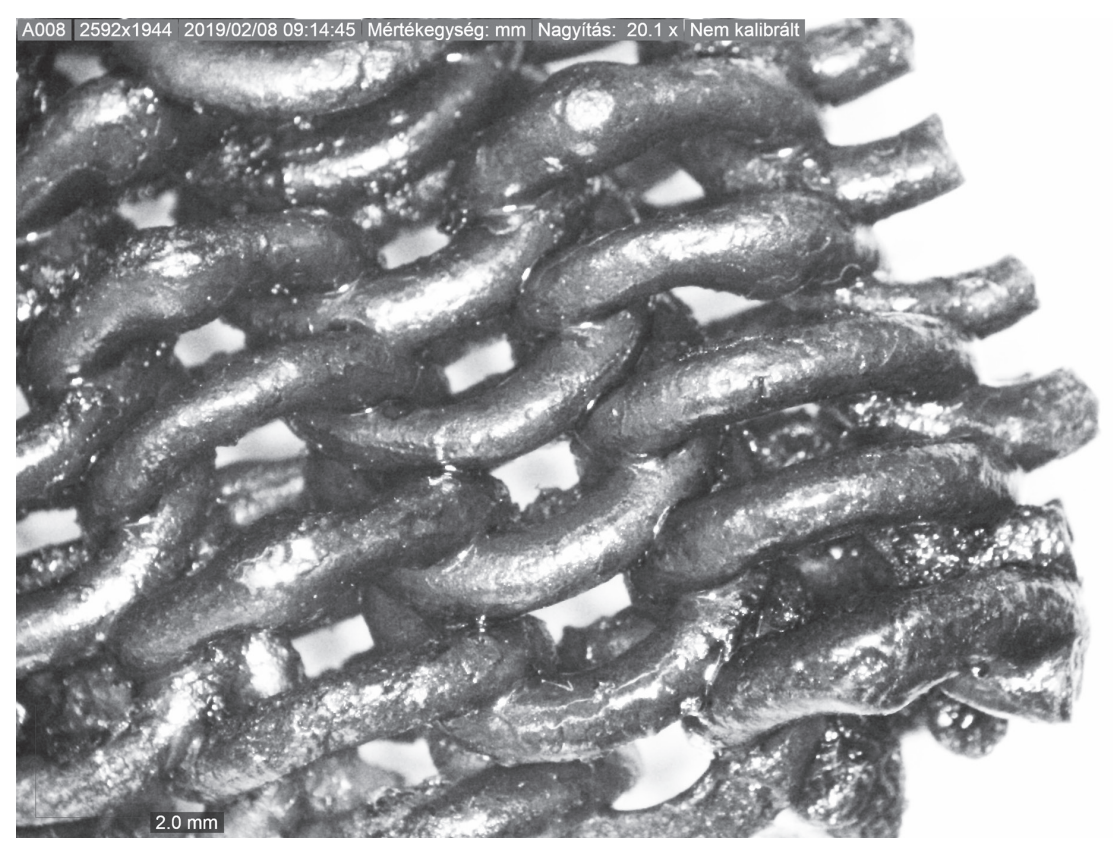

Fig. 7. On the microscope photo of the Csengersima mail, thickening of the rings referring to welding can be well observed 
As to the method of coating the scales with some precious metal - leafing: precious metal beaten into a thin plate and applied to the armour (Sim, Kaminski 2012, 74-75) -, there are several data from the Roman Age. First of all, we have a written source, according to which Consul Flaminius, participant of the Second Punic War had a "breastplate; its twisted links were embossed with plates wrought of hard steel mingled with gold" (Sil.It. V.140-141). There are several, not always matching translations of Statius' locus, but they all agree that the armour in question was a combination of rings and scales, the latter covered with gold (Wijnhoven 2009, footnote 7). Second, we know that different kinds of coating were applied for scales, like the already mentioned tinning, or the case of the lorica plumata from Vize/Bizye (Turkey), an elite Thracian burial, where bronze scales were covered with silver (Wijnhoven 2009, 13). Last, but not least, there are colour representations (fresco, mosaics) where armour is depicted white or silver and sometimes yellow/gold (Sim, Kaminski 2012, 69).

Summarising our present knowledge on the armour from Csengersima, we can assume that at the moment it should be considered unique both in the Roman and Barbarian world. Most of all, it reminds the mentioned cases of lorica plumata and can be related to the technology of covering the scales with some kind of bright material. However, we haven't succeeded in finding any exact analogies to the scales of Csengersima either in archaeological, or in iconographic material. All we can determinedly state is that this armour produced by special individual order, belonged to an outstanding, high ranking person of the contemporary Barbarian society.

\section{REFERENCES}

Beninger E.

1931 Der Wandalenfund von Czéke-Cejkov, Ann. Naturhist. Mus. Wien 45, p. 183-224. Budinský-Krička V., Lamiová-Schmiedlová M.

1990 A Late 1st Century B.C.-2nd Century A.D. Cemetery at Zemplín, Slovenská Archeológia 37/2, p. 245-344.

Czarnecka K.

2013 Warriors in this world and the afterlife. Przeworsk culture graves containing weapons, [in:] XVII Roman Military Equipment Conference Zagreb 2010 24th27th May, 2010 Radovi XVII. ROMEC-a Rimska vojna oprema u pogrebnom kontekstu. Proceedings of the XVIIth Roman Military Equipment Conference. Weapons and Military Equipment in a Funerary Context. Akten der 17. Roman Military Equipment Conference Militaria als Grabbeilage, M. Sanader, A. RendićMiočević, D. Tončinić, I. Radman-Livaja (eds.), Zagreb, p.163-175.

Gindele R.

2010/2011 A császárkori és kora népvándorlás kori anyagi kultúra fejlődésének aspektusai Északnyugat-Románia területén, Aspectele evoluției culturii materiale din 
spațiul nord-vest al României în epoca romană şi începutul epocii migrațiilor. Probleme betreffend die Entwicklung der Sachkultur in den 2 - 5. Jh. im Nordwesten Rumäniens, [in:] Erdély és kapcsolatai a kora népvándorlás korában. Molnár István Múzeum Kiadványai 3, Zs. Körösfőii (ed.), Székelykeresztúr, p. 205-248. Gindele R., Istvánovits E.

2009 Die römerzeitliche Siedlung von Csengersima-Petea, Satu Mare.

2011 The Roman-age settlement at Csengersima-Petea and pottery workshops from the Upper Tisza Basin, [in:] The Roman Empire and Beyond: Archaeological and Historical Research on the Romans and Native Cultures in Central Europe, E.C. De Sena, H. Dobrzańska (eds.), BAR International Series 2236, p. 85-103.

Godłowski K., Wichman T.

1998 Chmielów Piaskowy. Ein Gräberfeld der Przeworsk-Kultur im ŚwiętokrzyskieGebirge, Monumenta Archaeologica Barbarica 6, Kraków.

Istvánovits E., Kulcsár V.

2017 Sarmatians. History and archaeology of a forgotten people, Monographien des Römisch-Germanischen Zentralmuseums 123, Mainz.

Jakab A., Istvánovits E.

2011 Csengersima. Történelmi és kulturális kalauz. - Ghid cultural şi istoric. Historical and cultural guide, Nyíregyháza.

Janaczek H.

1990 Kurhany kultury Przeworskiej, Przegląd Archeologiczny 37, p. 121-155.

Jaskanis J.

2005 Krupice. Ein Gräberfeld der Przeworsk und Wielbark-Kultur in Ostpolen, Monumenta Archaeologica Barbarica 10, Warszawa.

Karpińska A.

1926 Kurhany z okresu rzymskiego w Polsce ze szczególnym uwzględnieniem typu siedlemińskiego, Poznań.

Kobály J.

1998 A Przeworsk kultúrához tartozó harcossírok és fegyverleletek a Kárpátalján [Römerzeitliche Waffenbestattungen in der Karpatoukraine und die BarbarenangrifKostrzewski J.

fe auf den Limes.], A Nyíregyházi András Múzeum Évkönyve 39-40, p. 113-126.

1917 Siedlemin $i$ okolica pod względem archeologicznym. Szkic monograficzny. Roczniki Tow. Przyj. Nauk Poznańskiego 44, Poznań.

Kotigorosko V.G.

1988 III. századi harcos sírja Bátyú (Bratovo) határában. [Grab eines Kriegers aus dem 3. Jhr. in der Gemarkung von Bratovo (Karpaten-Ukraine)], A Nyíregyházi Jósa András Múzeum Évkönyve 21-23, 1978-1980, p. 5-18.

Lehoczky T.

1892 Adatok hazánk archaeológiájához, különös tekintettel Bereg megyére s környékére.

I. Az ôskortól a magyarok bejöveteléig, Munkács.

Liana T.

1970 Chronologia względna kultury przeworskiej we wczesnym okresie rzymskim, Wiadomości Archeologiczne 35, p. 429-491.

Macrea M.

1957 Şantierul arheologic Caşolț - Arpaşul de Sus Raport preliminar asupra rezultatelor din campania anului 1955, Археологические раскопки в Кашолие - Арпашуле де Сус, Materiale şi cercetări arheologice 4, p. 119-154. 
Madyda-Legutko R., Pohorska-Kleja E., Rodzińska-Nowak J.

2006 Osada zokresu rzymskiego w Pakoszówce, stan. 1, pow. Sanok. Rocznik Przemyski 42(6), z. 2, Archeologia, p. 69-83.

Madyda-Legutko R., Rodzińska-Nowak J., Zagórska-Telega J.

2013 New data concerning the cultural situation in the basin of the Upper San River during the Roman Period, A Nyíregyházi Jósa András Múzeum Évkönyve 55, p. $409-422$.

Matei Al., Stanciu I.

2000 Vestigii din epoca Romană (sec. II-IV. p. Chr.) în spațiul Nord-Vestic al României [Funde der römischen Kaiserzeit (2.-4. Jh. n. Chr.) im Nordwestgebiet Rumäniens], Bibliotheca Musei Porolissensis II, Talău-Cluj-Napoca.

Mihalik J.

1892 Az úrmezei urnatemetô, Archaeologiai Értesítő 12, p. 95-96.

Olędzki M.

1999 The Upper Tisza Basin in the Roman Period. Remarks on Settlement and Cultural Changes, [in] Das mitteleuropäische Barbaricum und die Krise des römischen Weltreiches im 3. Jahrhundert, J. Tejral (ed.), Brno, p. 105-136.

2014 The Przeworsk culture and the problem of dating of the beginnings of the Blažice-Bereg culture, [in] Sociální diferenciace barbarských komunit ve světle nových hrobových, sídlištních a sběrových nálezů. Archeologie barbarů 2011, B. Komoróczy (ed.) Brno, p. 317-333.

Prohászka P.

2006 Das vandalische Königsgrab von Osztrópataka (Ostrovany, SK), Budapest.

Rajtár J.

1996 Waffen und Ausrüstüngteile aus dem Holz-Erde-Lager vom Iža, [in:] Military Equipment in Context: Proceedings of the Ninth International Roman Military Equipment Conference, Leiden 1994, C. van Driel-Murray (ed.), Oxford, p. 83-95.

Sim D., Kaminski J.

2012 Roman Imperial Armour. The Production of Early Imperial Military Armour, Oxford. Stanciu I., Matei A.V.

2006 Un cimitir din perioada de început a epocii romane imperiale târzii în nord-vestul României (Badon-„Doaşte”, com. Hereclean, jud. Sălaj), [Ein Friedhof aus der Anfangszeit der spätrömischen Kaiserzeit im Nordwesten Rumäniens (Badon - "Doaște", Kreis Sălaj)], [in:] Fontes Historiae: Studia in homorem Demetrii Protase, C. Gaiu, C. Găzdac , C. Cristian (eds.), Bistrița-Cluj-Napoca, p. 587-607.

Stephenson I.P.

2001 Roman Infantry Equipment. The Later Empire, Stroud.

Szathmáry L.

1988 Anthropological Investigations of the Cremated Remains of the Kurgan 1. of Bratovo (The Carpatian Ukraine), A Nyíregyházi Jósa András Múzeum Évkönyve 21-23, 1978-1980, p. 19-24.

Waurick G.

1982 Die römische Kettenrüstung von Weiler-la-Tour, Hémecht 34, p. 111-30.

Wijnhoven M.A.

2009 Lorica Hamata Squamataque: A Study of Roman Hybrid Feathered Armour, The Journal of the Mail Research Society 2(1), p. 3-65.

Żychliński D.

2013 The Absence of Cremation Sites within Cemeteries of the Przeworsk and Wielbark 
Cultures in the Roman Period in Great Poland. Sociology and Anthropology 1(2), p. 111-117.

Vakulenko L.V.

2004 Vzaimosvâzi kul'tur pozdnerimskogo vremeni Karpatskogo $i$ DneproDnestrovskogo regionov, [in:] Kul'turnye transformacii $i$ vzaimovliâniâ $v$ Dneprovskom regione na ishode rimskogo vremeni $i$ v rannem Srednevekov'e, Rossijskaâ akademiâ nauk Institut istorii material'noj kul'tury, Trudy XI, V.M. Gorûnova, O.A. Ŝeglova (eds.), Sankt-Peterburg, p. 96-107.

Kotigoroško V.G.

1977 Issledovanie pamâtnikov I tysâčeletiâ na territorii Zakarpat'â, [in:] Arheologičeskie otkrytiâ 1976, Moskva, p. 229-247.

1980 Itogi izučeniâ mogil'nika Iza I v Zakarpat'e, [Results of investigations of the cemetery Iza I in Transcarpathia], Sovetskaâ arheologiâ 1, p. 220-247.

1991 Kul'tury rimskogo vremeni, [in:] Drevnââ istoriâ Verhnego Potis'â, I.M. Grančak, V. Červenâk (eds.), L'vov, p. 147-148.

1998 Kurgan pozdnerimskogo vremeni vozle s. Lazur' Satu-marskogo uezda Rumynii, [The Mound of the Late-Roman Period Near the Village Lazury (Satu Mare Region)], Carpatica 5, p. 129-140.

Rusanova I.P.

1993 Kul'tura kapratskih kurganov, [in:] Slavâne i ih sosedi v konce I tysâčeletiâ do n.é. - pervoj polovine I tysâčeletiâ n.é., Arheologiâ SSSR, I.P. Rusanova, É.A. Smiško M.Û. Symonovič (eds.), Moskva, p. 171-181.

1952 Dva kurganni mogil'niki v okolicâh s. Izy, Zakarpats'kö̈ oblasti [in:] Arheologični pam'âtki YRSR 3, Kyïv, p. 315-336.

1960 Karpats'ki kurgany peršoï polovyny I tysâčolittâ n.e., Kyïv.

\section{Ancient sources}

Silius Italicus

Punica. Books I-VIII. With an English translation by J.D. Duff. Loeb Classical Library 277, Cambridge - London 1934.

Addresses of the Authors

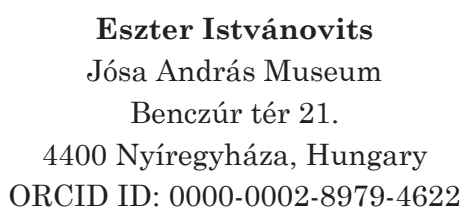

Eszter Istvánovits

Benczúr tér 21.

ORCID ID: 0000-0002-8979-4622

\author{
Valéria Kulcsár \\ Department of Archaeology \\ Faculty of Humanities \\ University of Szeged \\ Egyetem u. 2. \\ 6722 Szeged, Hungary \\ ORCID ID: 0000-0003-4351-9227
}


